\title{
Time-frequency transforms in analysis of non-stationary quasi-periodic biomedical signal patterns for acoustic anomaly detection
}

A. O. Iskhakova a,b, PhD, Tech., Senior Researcher, orcid.org/0000-0001-8358-298X, iskhakova.ao@gmail.com

M. D. Alekhinc, PhD, Tech., Head of Department of Biomedical Engineering, orcid.org/0000-0003-2091-2755

A. V. Bogomolovd, Dr. Sc., Tech., Professor, Leading Researcher, orcid.org/0000-0002-7582-1802

aV. A. Trapeznikov Institute of Control Sciences of RAS, 65, Profsoyuznaya St., 117997, Moscow,

Russian Federation

bTomsk State University of Control Systems and Radioelectronics, 40, Lenina Pr., 634050, Tomsk, Russian Federation

cJSC «RPA «Electronic Device Engineering», 2, 2nd Boyevskaya St., 107104, Moscow, Russian Federation

${ }^{\mathrm{d} B u r n a z y a n}$ Federal Medical and Biophysical Center of Federal Medical Biological Agency, 23, Marshala

Novikova St., 123098, Moscow, Russian Federation

Introduction: New approaches to efficient compression and digital processing of audio signals are relevant today. There is a lot of interest to new pattern recognition methods which can improve the quality of acoustic anomaly detection. Purpose: Comparative analysis of methods for time-frequency transformation of audio signal patterns, including non-stationary quasiperiodic biomedical signals in the problem of acoustic anomaly detection. Results: The study compared different time-frequency transforms (such as windowed Fourier, Gabor, Wigner, pseudo Wigner, smoothed pseudo Wigner, Choi - Williams, Bertrand, pseudo Bertrand, smoothed pseudo Bertrand, and wavelet transforms) based on systematization of their functional characteristics (such as the existence and limitedness of basis functions, presence of zero moments and biorthogonal form, opportunity of two-dimensional representation and inverse transformation, real time processing, time-frequency transform quality, control of time-frequency definition, time and frequency interference suppression, relative computational complexity, fast algorithm implementation) for the problem of biomedial signal pattern recognition. A comparative table is presented with estimates of information capacity for the considered time-frequency transforms. Practical relevance: The proposed approach can solve some acoustic anomaly detection algorithm implementation problems common in non-stationary quasi-periodic processes, in order to study disruptive effects causing a change in the functional state of ergatic system operators.

Keywords - system analysis, non-stationary quasi-periodic processes, pattern recognition, biomedical signal processing, ergatic systems, functional states, disruptive effect, time-frequency transforms, acoustic anomaly detection, frequency deviation, noise.

For citation: Iskhakova A. O., Alekhin M. D., Bogomolov A. V. Time-frequency transforms in analysis of non-stationary quasiperiodic biomedical signal patterns for acoustic anomaly detection. Informatsionno-upravliaiushchie sistemy [Information and Control Systems], 2020, no. 1, pp. 15-23. doi:10.31799/1684-8853-2020-1-15-23

\section{Introduction}

"The Colosseum", a massive radiofrequency channel emulator run by Defense Advanced Research Projects Agency (DARPA) Spectrum Collaboration Challenge (SC2), is transitioning to the Platform for Advanced Wireless Research (PAWR) after a final spectrum competition, matchup at Mobile World Congress Los Angeles on October 23, 2019 [1]. It means that advanced research will grow rapidly on solutions [2], enabling radio networks to autonomously collaborate and dynamically determine spectrum use from moment to moment, using modern time-frequency transformation instruments on feature extraction phase.

Initially, the progress in the field of quantum statistics formed the foundation for time-frequency (TF) analysis of non-stationary quasi-periodic biomedical (NQB) signals [3]. The first classical pub- lications of Gabor and Ville were due to the trends in quantum mechanics, the mathematical apparatus of which has similar features to the TF analysis of NQB signals. In 1946, Gabor developed an original method, closely related to coherent states in quantum mechanics [4]. In the same publication, an important concept of the analytic signal was introduced. Two years later, Ville [5] modified the distribution, first used by Wigner to study quantum statistics.

In the early 1980s researchers paid close attention to the study of orthogonal systems of basises of general form, which led to the emergence of a generalized theory of spectral analysis. In 1982 Morlet in his publication [6] addressing the study of seismic signals introduced the concept of the basis function of wavelet transform (WT). This study is reflected in many works on this subject and is used for research of seismically unstable objects and territo- 
ries. In particular, works devoted to assessing the characteristics of volcanoes and creating models and calculations for timely response to changes in their values [7, 8].

An important contribution to the WT theory was made by Daubechies, who in 1988 developed a class of basises for orthogonal wavelets [9] of the same name. The created family of orthogonal wavelets with the compact carrier calculated in the iterative way further was investigated and applied to a solution of different applied tasks. It is now represent an effective mathematical apparatus in NQB signal pattern analysis and recognition [10-12], as well as for geophysical [13, 14], neurophysiological [15], acoustics [16-18], safety and security [19-21], reconnaissance [22, 23], and bio-radiolocation [24, 25] problems solving and are popular in other interdisciplinary fields of science and technology [26-28].

It should be noted, that each TF transform has its own strengths and weaknesses, and particular transform type should be selected each time, based on the conditions of the applied tasks of NQB signal processing [29]. The analysis of TF transforms should be performed systematically, allowing to take into consideration advantages and disadvantages of their properties, to improve the quality of NQB signal processing [30].

Thus, the present work is aimed at performing comparative analysis of TF transforms based on systematization of their main characteristics in the problems of processing of NQB signals patterns, using the example of test low-frequency biomedical signal realization (Fig. 1).

The novelty of the study is in providing an informative instrument in a form of a comparative table clearly systemizing functional characteristics of considered TF transformations for justified selection a set of them for sensible identification of non-stationary anomalies, applying digital signal processing techniques on the next stages. The validity of the proposed approach can be further strengthened using expert methods and broadening the classes of analyzed signal classes in the search of concrete particularities in both time and

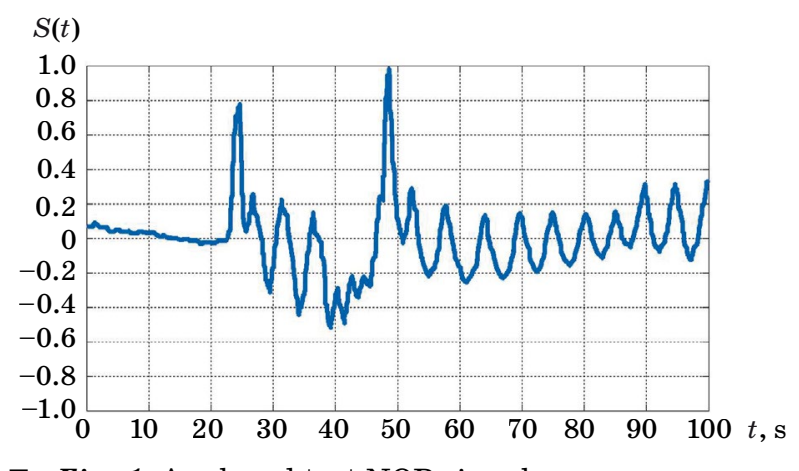

- Fig. 1. Analyzed test NQB signal frequency domains. Thus, unification of signal representation and formalization of classification and clusterization tasks lead to founding a novel method for automated pattern recognition for non-stationary quasi-periodic processes on the base of simultaneous application of convolutional neural networks and a set of TF transformations, selected by the maximum of entropy heterogeneity [31].

\section{The applicability of time-frequency transformations in practical tasks of sound analysis in a virtual environment}

Time-frequency transformations allow to extract various characteristics of audio signals. Therefore, it can be used to solve the plenty of practical tasks related to monitoring and tracking of audio materials, analysis and decision making [32-34].

In particular, such an implementation with data mining elements is typical for the design of socio-cyberphysical systems (SCPS) - systems that are characterized by decision making directly by its own elements. As described in [35], the decision scheme in the SCPS is based on the analysis of the data by the cybernetic component based on the context and the corresponding plurality of valid decisions. The cyberphysical system receives data that is delivered by different kinds of sensors, actuators, tags, tokens and other types of electronic devices. The cybernetic component processes this data and forms the context. The context provides information that allows to take a look at the current state of the system environment. It is the basis for generating the plenty of possible solutions. The decision making process is supported by communication and interaction between system components. Information from cybernetic to cybernetic, from cybernetic to human, from human to cybernetic, from cybernetic and human to central repository, and from central repository to cybernetic and human is shared throughout the decision-making scheme [36].

One of the most advanced and complex SCPS is the cyber environment formed by the Internet. The main features of this SCPS are [37]:

- the large amount of data distributed in the system;

- heterogeneity of data: different data types, for example, texts, graphic files, audio signals, and the mixed varieties, for example, for example, video streams which integrate a visual stream and an audio stream;

- high speed of data distribution in the system;

- a large number of users (people) in the system;

- the distributed cybernetic component for decision making; 
- various forms of a context, which is the basis for generation of possible decisions at identification of a problem;

- delayed and not always obvious reaction of the system operators to events and decisions in the system.

Time-frequency transformations allow to extract and calculate different characteristics of audio signals and theirs values, in this particular case audio files - elements of a virtual environment. That is why this methods can be used to solve practical problems related to monitoring and tracking of audio materials, their analysis and decision-making.

An example of such a problem situation is the identification of various anomalies, such as frequency deviations, noise effects and other "emissions". Their presence may indicate abnormal sound of the material, including the presence of destructive effect on the listener (operator) and be the reason for change of its condition [38].

In this problem situation it is possible to select three main premises for emergence of an indisposition and unpleasant feelings at the user of virtual environment who periodically or is regularly affected: existence of elastic fluctuations that are unheard a human ear - with a frequency below 16 $\mathrm{Hz}$ (infrasound) or is higher than $20,000 \mathrm{~Hz}$ (ultrasound), and also existence of vibrations. These sound anomalies (for a human ear) can be shown in acoustic record as it is constant throughout, and in separate timepoints or with some period.

Thus, the application of $\mathrm{TF}$ transformation methods may allow to identify and recognize different characteristics and features of audio signals and can be used for monitoring of audio streams in the SCPS operating in virtual environment.

\section{Comparative analysis of time-frequency transforms}

\section{Linear time-frequency transforms}

\section{Windowed Fourier transform}

In windowed Fourier transform (WFT), spectral density function $S_{\text {WFourier }}(\omega, \tau)$ for signal $s(t)$ is defined [39] by the formula

$$
S_{\text {WFourier }}(\omega, \tau)=\int_{-\infty}^{+\infty}(s(t) w(t-\tau) \exp (-i \omega t)) \mathrm{d} t
$$

The idea of traditional Fourier transform, with the disadvantage in the lack of information about the position of the frequency components on the time axis, was improved into the WFT (Fig. 2). It has a constant time resolution and enables identifying the features of long-period components of NQB

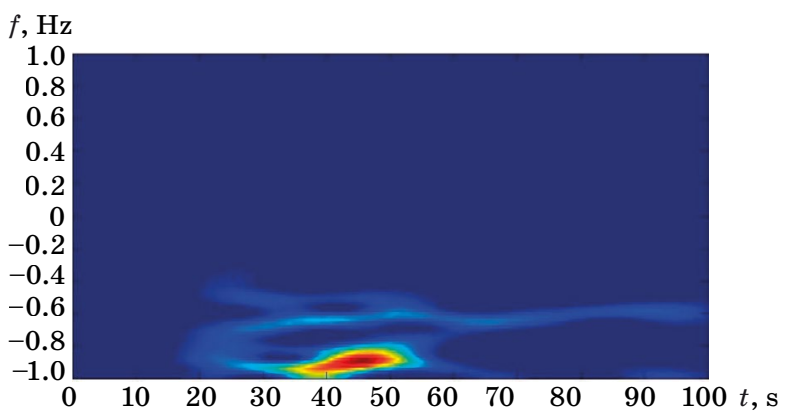

Fig. 2. Result of WFT application (Hamming window) for the test NQB signal realization

signals. However, a significant shortcoming of the WFT is the lack of localization of the basis functions. The influence of local features on the form of the function of WFT spectral density is limited in time only by the width of the window. At the same time, the advantage of the WFT include a wide range of various window functions [40].

\section{Gabor transform}

In Gabor transform (GT), spectral density function $S_{\text {Gabor }}(\omega, \tau)$ for signal $s(t)$ is defined [39] by the formula

$$
\begin{gathered}
S_{\text {Gabor }}(\omega, \tau)= \\
=\frac{1}{\left(\pi \sigma^{2}\right)^{\frac{1}{4}}} \int_{-\infty}^{+\infty}\left(s(t) \exp \left(-\frac{(t-\tau)^{2}}{2 \sigma^{2}}\right) \exp (-i \omega t)\right) \mathrm{d} t .
\end{gathered}
$$

Gabor transform is a kind of WFT with a Gaussian window (Fig. 3). The main advantage of GT is that it has a good TF localization. There is also reverse GT. At the same time, the lack of self-similarity of the basis should be treated as a shortcoming of GT. Thus, each time for different scales of the period, a different number of periods of the harmonic function falls into the GT window. The analyzed signal is actually decomposed into

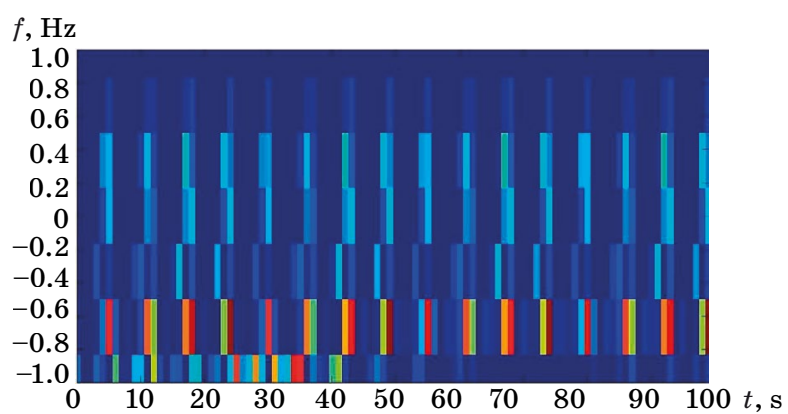

- Fig. 3. Result of GT application for the test NQB signal realization 


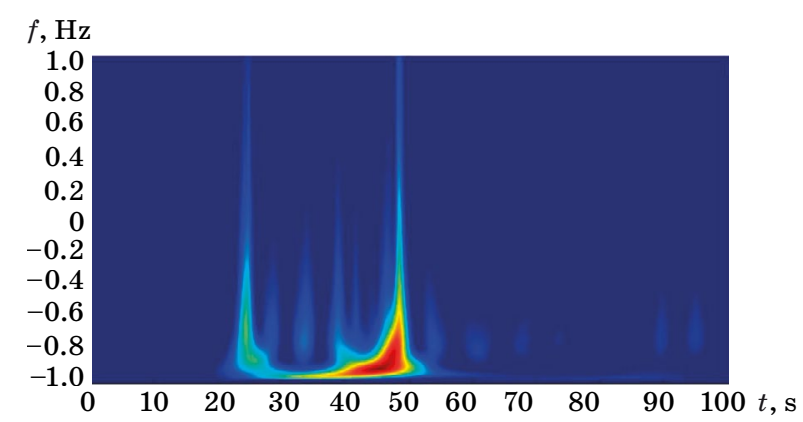

Fig. 4. Result of WT application (Morlet basis) for the test NQB signal realization

different basis functions, rather than into the same one, as for example, in the case of WT [40].

\section{Wavelet transform}

In Wavelet transform (WT), spectral density function $S_{\text {Wavelet }}(\omega, \tau)$ for signal $s(t)$ is defined [39] by the formula

$$
S_{\text {Wavelet }}(\omega, \tau)=\left|k \frac{2 \pi}{\omega}\right|^{-\frac{1}{2}} \int_{-\infty}^{+\infty}\left(s(t) \psi\left(\frac{\omega(t-b)}{2 \pi k}\right)\right) \mathrm{d} t .
$$

The main concept of WT is based on analysis of a signal with different resolutions, also called a multiple-scale wavelet analysis (MSWA), generating orthogonal and biorthogonal forms (Fig. 4). In biorthogonal WT, the signal is decomposed applying the method of cross-use of mutually orthogonal basis functions. The main advantages of WT are the good localization of basis functions with respect to time and frequency, and, as a consequence, high TF resolution, which enables a detailed investigation of the local features of NQB signals. A wide choice of basis functions of WT and the possibility of their customized construction enables the selection of the optimal parameters of WT for each particular problem. However, the shortcomings of WT are dependence of the wavelet spectrum of the analyzed signal on the type of the selected mother wavelet and subjectivity of its choice [40].

\section{Bilinear time-frequency transforms}

\section{Wigner transform}

In Wigner transform (WGT), spectral density function $S_{\text {Wigner }}(\omega, \tau)$ for signal $s(t)$ is defined [39] by the formula

$$
S_{\text {Wigner }}(\omega, \tau)=\int_{-\infty}^{+\infty}\left(s\left(\tau+\frac{t}{2}\right) s^{*}\left(\tau-\frac{t}{2}\right) \exp (-i \omega t)\right) \mathrm{d} t \text {. }
$$

The main advantage of WGT is its good TF resolution (Fig. 5). There is also reverse WGT. Its short-

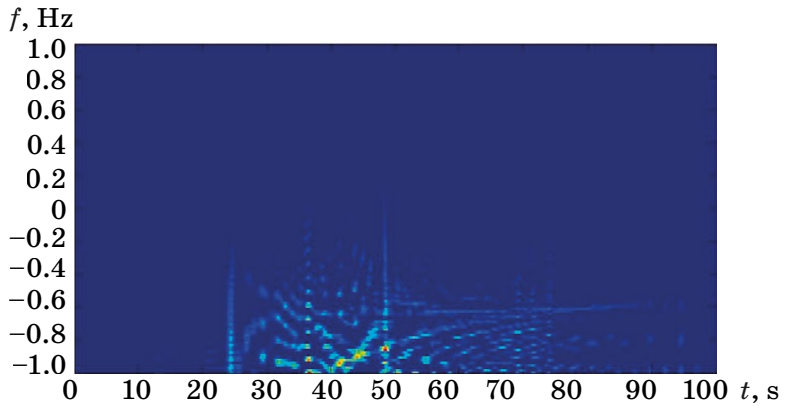

- Fig. 5. Result of WGT application for the test NQB signal realization

coming is the presence of interference terms of the spectral density function for multicomponent NQB signals.

However, there are methods that make it possible to substantially mitigate the effects of the influence of these interference terms using averaging procedures. For example, the introduction of an additional time window function in calculating WGT leads to pseudo Wigner transform (PWGT). But excessive narrowing of the window causes the TF representation to blur on the TF plane in most of the cases. The additional weight function helps to mitigate the frequency interference terms, which founds smoothed pseudo Wigner transform (SPWGT) [40].

\section{Choi - Williams transform}

In Choi - Williams transform (CWT), spectral density function $S_{\text {Choi-W }}(\omega, \tau)$ for signal $s(t)$ is defined [39] by the formula

$$
\begin{gathered}
S_{\text {Choi- }}(\omega, \tau)=\left(\sqrt{\frac{\sigma}{4 \pi}}\right) \int_{-\infty}^{+\infty}\left(\frac{1}{|t|} \exp (-i \omega t)\right) \times \\
\times \int_{-\infty}^{+\infty}\left(\exp \left(-\frac{(u-\tau)^{2} \sigma}{4 t^{2}}\right) s\left(\tau+\frac{t}{2}\right) s^{*}\left(\tau-\frac{t}{2}\right)\right) \mathrm{d} u \mathrm{~d} t
\end{gathered}
$$

Implementation of this bilinear TF transform enables reducing the intensity of the interference

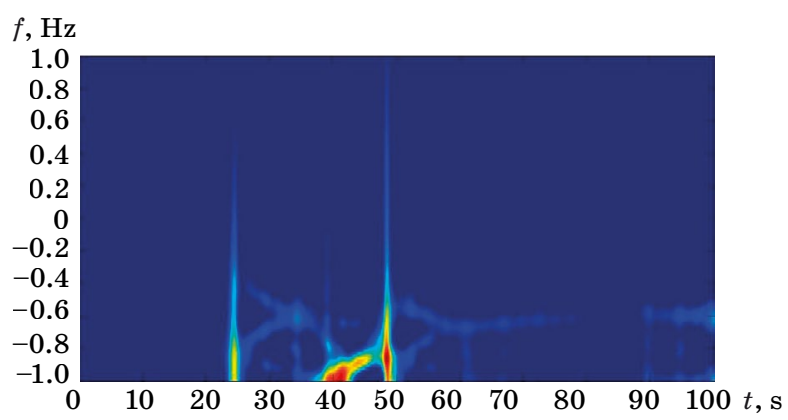

Fig. 6. Result of CWT application for the test NQB signal realization 
terms (Fig. 6). The main advantage of CWT is the ability to control the level of interference. Thus, in some applications, it is possible to select the optimum values of the parameters, at which the undesirable effects turn out to be quite well suppressed, and $\mathrm{TF}$ resolution remains acceptable within the framework of the solving problem. It is worth to note that the cases of successful CWT application includes a number of medical studies, which resulted in achieving a significant reduction in interference in the tasks of TF representation of biomedical signals [40].

\section{Bertrand transform}

In Bertrand transform (BT), spectral density function $S_{\text {Bertrand }}(\omega, \tau)$ for the signal $s(t)$ is defined [39] by the formula

$$
\begin{gathered}
S_{\text {Bertrand }}(\omega, \tau)= \\
=\int_{-\infty}^{+\infty} \frac{1}{|t|} \int_{\tau-\frac{t}{2}}^{\tau+\frac{|t|}{2}}\left(s\left(u+\frac{t}{2}\right) s^{*}\left(u-\frac{t}{2}\right) \exp (-i \omega t)\right) \mathrm{d} u \mathrm{~d} t
\end{gathered}
$$

In addition to the typical shortcoming associated with the existing interference of most bilinear TF transforms, the essential weakness of BT is the impossibility of its implementation in real time (Fig. 7). The pseudo Bertrand transform (PBT) is better in some aspects: asymptotically having the same properties as BT, it enables reducing the influence of interference terms along the frequency axis and allows real-time implementation. For simultaneous interference reduction along the time and frequency axes, the smoothed pseudo Bertrand

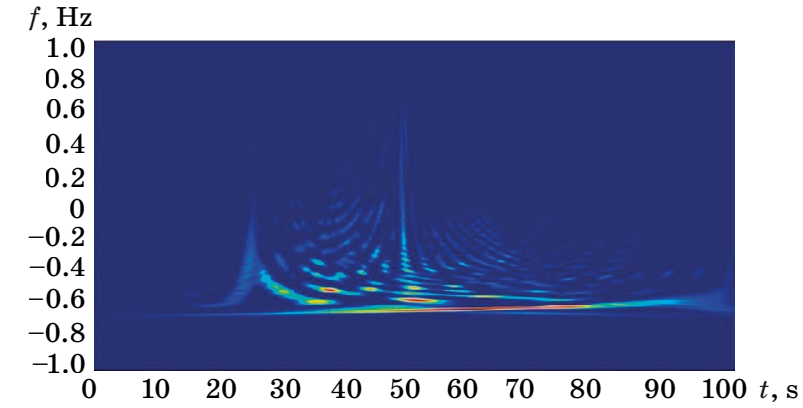

- Fig. 7. Result of BT application for the test NQB signal realization

transform (SPBT) was developed, which has an additional smoothing frequency window function [40].

\section{Results of the comparison and systematization}

The results of systematization of the main characteristics of discussed TF transforms in analysis of NQB signals patterns are provided in Table.

Table shows the transformation designations as follows:

WFT - window Fourier transform;

GT - Gabor transform;

WT - Wavelet transform;

WGT - Wigner transform;

PWGT - pseudo Wigner transform;

SPWGT - smoothed pseudo Wigner transform; CWT - Choi - Williams transform;

BT - Bertrand transform;

PBT - pseudo Bertrand transform;

SPBT - smoothed pseudo Bertrand transform;

\begin{tabular}{|c|c|c|c|c|c|c|c|c|c|c|}
\hline Characteristic & WFT & GT & WT & WGT & PWGT & SPWGT & CWT & BT & PBT & SPBT \\
\hline I & \pm & \pm & + & \pm & \pm & \pm & \pm & - & - & - \\
\hline II & + & + & + & - & - & - & - & - & - & - \\
\hline III & - & - & + & + & + & + & + & - & - & - \\
\hline IV & - & + & + & - & - & - & - & - & - & - \\
\hline $\mathrm{V}$ & + & + & + & + & + & + & + & - & - & - \\
\hline VI & + & + & + & + & + & + & + & - & - & - \\
\hline VII & + & + & + & + & + & + & + & - & + & + \\
\hline VIII & ++ & ++ & +++ & ++ & + & + & ++ & ++ & + & + \\
\hline IX & + & + & ++ & - & - & - & ++ & - & - & - \\
\hline $\mathrm{X}$ & ++ & - & ++ & - & + & + & + & - & + & + \\
\hline $\mathrm{XI}$ & ++ & - & ++ & - & - & + & + & - & - & + \\
\hline XII & ++ & ++ & ++ & + & \pm & - & \pm & + & \pm & - \\
\hline XIII & - & - & + & - & - & - & - & - & - & - \\
\hline
\end{tabular}

Systematization of characteristics of TF transforms 
and the characteristics of the transforms are as follows:

I - presence of basis functions;

II - finiteness of basis functions;

III - presence of zero times;

IV - presence of a biorthogonal form;

$\mathrm{V}$ - presence of a two-dimensional form;

VI - possibility of reverse transform;

VII - possibility of real time processing;

VIII - time-frequency localization;

IX - resolution control;

$\mathrm{X}$ - time interference suppression;

$\mathrm{XI}$ - frequency interference suppression;

XII - computational complexity;

XIII - presence of a fast computational algorithm.

Thus, comparative analysis of the TF transforms in processing of $\mathrm{NQB}$ signals reveals that linear TF transforms, such as WFT and GT, do not have sufficiently good time and frequency localization properties at the same time. Generally, good frequency resolution is accompanied by worse time localization, and an increase of the time resolution reduces the frequency resolution.

In turn, bilinear TF transforms have satisfactory characteristics of localization on the TF plane, but their essential drawback is the existence of interference terms. In the modified bilinear WT and BT, the interference is eliminated with smoothing time and frequency windows, but this simultaneously results in a worse time and frequency resolution, accordingly. The latter circumstance explain the overall advantages and prospects of using these TF transforms in practical applications of NQB signal precise structure analysis. The relatively high complexity and lack of fast computational algorithms for the bilinear TF transforms significantly hinder their application in the tasks of real-time NQB signals processing.

\section{Conclusion}

The comparative values of application of the main time-frequency transforms methods for processing of a test non-stationary quasi-periodic biomedical signal showed that basic time-frequency methods can be used in different tasks of identifying audio signals features. Based on the given results it can be concluded, that WT has one of the best properties in the terms of TF localization which makes it especially efficient for informative features extraction for attribute space forming in the tasks of automated recognition of NQB signals patterns. Availability of variety of existing mother wavelets and the possibility of construction of customized basis functions give the opportunity to select the optimal basis of WT on the strength of properties and character peculiarities of analyzed NQB signals. The choice of the method also depends on the practical task being solved. For example, the problem of detecting sound anomalies in audio materials, that are spread in the virtual environment, can be better solved using such methods as WFT, WT, WGT, as they are more accurate in determining low frequency inclusions and (if present) vibrations.

\section{Financial support}

The present work was performed in the framework of "BioSpectrum" perspective program (JSC "RPA “Electronic Device Engineering") supported by grant of the President of the Russian Federation for leading scientific schools NSh-2553.2020.8 and RFBR projects no. 18-29-22104, no. 18-08-00244, no. 20-013-00306.

\section{References}

1. SC2 Spectrum Collaboration Challenge - Using AI to Unlock the True Potential of the RF Spectrum. Available at: https://www.spectrumcollaborationchallenge.com/ (accessed 13 December 2019).

2. Klabukov I. D., Yakovets A. V., Alekhin M. D. Management of systems engineering and technical assistance of DARPA research programs. Innovatsii, 2017, no. 5(223), pp. 12-19 (In Russian).

3. Malfante M., Mars J., Mura M. D., Gervaise C. Automatic fish sounds classification. The Journal of the Acoustical Society of America, 2018, vol. 143, pp. 2834-2846, doi:10.1121/1.5036628

4. Gabor D. Theory of communication. Part 1: The analysis of information. IEE Proceedings, 1946, vol. 93, iss. 26, pp. 429-457, doi:10.1049/ji-3-2.1946. 0074
5. Ville J. Theorie et applications de la notion de signal analytique. Cables et Transmission, 1948, vol. 2, no. 1, pp. 61-74 (In French).

6. Morlet J., Arens G., Fourgeau I., Giard D. Wave propagation and sampling theory. Geophysics, 1982, vol. 47(2), pp. 203-236. doi:10.1190/1.1441329

7. Malfante M., Mura M. D., Metaxian J.-P., Mars J., Macedo O., Inza L. A. Machine learning for volcano-seismic signals: Challenges and perspectives. IEEE Signal Processing Magazine, 2018, vol. 35, pp. 20-30. doi:10.1109/MSP.2017.2779166

8. Hammer C., Beyreuther M., Ohrnberger M. A Seismic-event spotting system for volcano fast-response systems. The Bulletin of the Seismological Society of America, 2102, vol. 102, pp. 948-960. doi:10.1785/ 0120110167

9. Daubechies I. Orthonormal bases of compactly supported wavelets. Communications on Pure and Ap- 
plied Mathematics, 1988, vol. 41, pp. 909-996. doi:10.1002/cpa.3160410705

10. Pankratov A. N., Pyatkov M. I., Tetuev R. K., Nazipova N. N., Dedus F. F. Search for extended repeats in genomes based on the spectral-analytical method. Mathematical Biology and Bioinformatics, 2012, vol. 7, pp. 476-492.

11. Alekhin M., Anishchenko L., Tataraidze A., Ivashov S., Korostovtseva L., Sviryaev Y., Bogomolov A. Selection of wavelet transform and neural network parameters for classification of breathing patterns of bio-radiolocation signals. Communications in Computer and Information Science, 2014, vol. 404, pp. 175-178. doi:10.1007/978-3-642-54121-6_15

12. Gorshkov Y. G. Visualization of multi level wavelet analysis of phonograms. Scientific Visualization, 2015, vol. 7, no. 2, pp. 96-111. Available at: http:// sv-journal.org/2015-2/08.php?lang=en (accessed 13 December 2019) (In Russian).

13. Mandrikova O. V., Solovjev I. S., Geppener V. V., Klionsky D. M. New wavelet based approach intended for the analysis of subtle features of complex natural signals. Pattern Recognition and Image Analysis, 2011, vol. 21, iss. 2, pp. 300-303. doi:10.1134/ S1054661811020726

14. Rao Y. S., Naresh K., Kumar M. K., Mahaboob S. Detection and minimization of harmonics using daubechies wavelet. International Journal of Applied Engineering Research, 2015, vol. 10, pp. 1188911908.

15. Khorev V. S., Maksimenko V. A., Pitcik E. N., Runnova A. E., Kurkin S. A., Hramov A. E. Analysis of motor activity using electromyogram signals. Informat sionno-upravliaiushchie sistemy [Information and Control Systems], 2019, no. 3, pp. 114-120 (In Russian). doi:10.31799/1684-8853-2019-3-114-120

16. Krasheninnikov V. R., Armer A. I., Khvostov A. V. Preparation of templates in speech command recognition by single and double channel scheme in background noise. Pattern Recognition and Image Analysis, 2008, vol. 18 , iss. 4, pp. 580-583. doi:10.1134/ S1054661808040068

17. Dragan S. P., Bogomolov A. V., Kotlyar-Shapirov A. D., Kondrat'eva E. A. A method for investigation of the acoustic reflex on the basis of impedance measurements. Biomedical Engineering, 2017, vol. 51, iss. 1, pp. 72-76. doi:10.1007/s10527-017-9687-6

18. Bogomolov A. V., Sviridyuk G. A., Keller A. V., Zinkin V. N., Alekhin M. D. Information-logical modeling of information collection and processing at the evaluation of the functional reliability of the aviation ergate control system operator. Proceedings of 2018 International Conference on Human Factors in Complex Technical Systems and Environments (ERGO), 2018, pp. 106-110. doi:10.1109/ERGO.2018.8443849

19. Lu T.-C., Chang C.-C., Liu Y.-L. A content-based image authentication scheme based on singular value decomposition. Pattern Recognition and Image Anal- ysis, 2006, vol. 16, iss. 3, pp. 506-522. doi:10.1134/ S1054661806030187

20. Shumskaya O. O., Zelezny M. Adaptive algorithm of replacement-based embedding of data into compressed JPEG images. Informatsionno-upravliaiushchie sistemy [Information and Control Systems], 2018, no. 5, pp. 44-56(In Russian). doi:10.31799/16848853-2018-5-44-56

21. Iskhakov A. Y. Adaptive authentication technologies in behavioral analysis solutions of robotic systems. Proceedings of the VIth International Workshop "Critical Infrastructures: Contingency Management, Intelligent, Agent-based, Cloud Computing and Cyber Security" (IWCI-2019), 2019. doi:10.2991/iwci-19.2019.10. Available at: https://www.atlantis-press.com/proceedings/iwci-19/125917301 (accessed 13 December 2019).

22. Yang Y., Sun H., Cao Y. Unsupervised urban area extraction from SAR imagery using GMRF. Pattern Recognition and Image Analysis, 2006, vol. 16, iss. 1, pp. 116-119. doi:10.1134/S1054661806010378

23. Iskhakov A. Yu., Iskhakova A. O., Meshcheryakov R. V., Bendraou R., Melekhova O. Application of user behavior thermal maps for identification of information security incident. SPIIRAS Proceedings, 2018, iss. 6(61), pp. 147-171 (In Russian). doi:10.15622/ sp. 61.6

24. Dafna E., Tarasiuk A., Zigel Y. Sleep staging using nocturnal sound analysis. Scientific Reports, 2018, vol. 8, article number 13474. doi:10.1038/s41598-01831748-0

25. Bai X., Jun D., Wang Z.-R., Lee C.-H. A hybrid approach to acoustic scene classification based on universal acoustic models. Interspeech 2019, 2019, pp. 3619-3623. doi:10.21437/Interspeech.2019-2171

26. Taylor J. Advanced Ultrawideband Radar: Signals, Targets, and Applications (Force Drawing Series). Boca Raton, CRC Press, 2016. 494 p.

27. Iskhakova A. O. Processing of big data streams in intelligent electronic data analysis systems. Proceedings of the VIth International workshop "Critical infrastructures: Contingency management, Intelligent, Agent-based, Cloud computing and Cyber secu rity" (IWCI-2019), 2019. doi:10.2991/iwci-19.2019.4. Available at: https://www.atlantis-press.com/proceedings/iwci-19/125917301 (accessed 13 December 2019).

28. Golovnin O. K., Stolbova A. A. Wavelet analysis as a tool for studying the road traffic characteristics in the context of intelligent transport systems with incomplete data. SPIIRAS Proceedings, 2019, vol. 18, no. 2, pp. 326-353 (In Russian). doi:10.15622/sp.18. $2.326-353$

29. Boashash B. Time-frequency signal analysis and pro cessing: A Comprehensive reference. $2^{\text {nd }} \mathrm{ed}$. Cambridge, Academic Press, 2015. 1056 p.

30. Cohen L. Time-frequency analysis. New Jersey, Prentice Hall, 1995. 299 p. 
31. Alekhin M. D., et al. Ustrojstvo dlya avtomaticheskogo raspoznavaniya patternov radiosignalov [A device for automated recognition of patterns of radiotechnical signals]. Patent RU, no. 175179. Published on 18.12.2017. Patent holder JSC "RPA "Electronic Device Engineering".

32.Zhdanko I. M., Zinkin V. N., Soldatov S. K., Bogomolov A. V., Sheshegov P. M. Fundamental and applied aspects of preventing the adverse effects of aviation noise. Human Physiology, vol. 42, pp. 705-714. doi:10.1134/S0362119716070227

33. Iskhakova A. O., Meshcheryakov R. V. Automatic search of the malicious messages in the Internet of things systems on the example of an intelligent detection of the unnatural agents requests. Proceedings of the 2nd Russia and Pacific Conference on Computer Technology and Applications (RPC), 2017, pp. 85-89. doi:10.1109/RPC.2017.8168074

34. Gorodetskiy A. E., Kurbanov V. G., Tarasova I. L. Decision-making in central nervous system of a robot. Informatsionno-upravliaiushchie sistemy [Information and Control Systems], 2018, no. 1, pp. 21-30 (In Russian). doi:10.15217/issn1684-8853.2018.1.21

35. Smirnov A. V., Levashova T. V. Models of decision support in socio-cyber-physical systems. Informatsionno-upravliaiushchie sistemy [Information and Control Systems], 2019, no. 3, pp. 55-70 (In Russian). doi:10.31799/1684-8853-2019-3-55-70
36. Smirnov A. V., Levashova T. V. Knowledge acquisition in socio-cyber-physical systems through information exchange between resources. Informatsion no-upravliaiushchie sistemy [Information and Control Systems], 2017, no. 6, pp. 113-122 (In Russian). doi:10.15217/issn1684-8853.2017.6.113

37. Tatarnikova T. M. Statistical methods for studying network traffic. Informatsionno-upravliaiushchie sistemy [Information and Control Systems], 2018, no. 5, pp. 35-43 (In Russian). doi:10.31799/1684-88532018-5-35-43

38. Dragan S. P., Bogomolov A. V., Kondrat'eva E. A. Mathematical model of polyharmonic signal processing to study the state of the tympanic membrane. 2016 International Conference on Engineering and Telecommunication (EnT), 2016, pp. 21-25. doi:10. 1109/EnT.2016.013

39. Auger F., Flandrin P., Goncalves P., Lemoine O. Time-frequency toolbox. For use with MATLAB: Reference guide. Houston, Rice University Press, 2005. Available at: http://tftb.nongnu.org/refguide.pdf (accessed 13 December 2019).

40. Chernogor L. F., Lazorenko O. V. System spectral analysis of the ultra-wideband signals. 2012 6th International Conference on Ultrawideband and Ultrashort Impulse Signals, 2012, pp. 243-245. doi:10.1109 /UWBUSIS.2012.6379794

УДК 004.93: 004.89: 004.048: 007.51

doi:10.31799/1684-8853-2020-1-15-23

Время-частотные преобразования в анализе паттернов нестационарных квазипериодических биомедицинских сигналов для задач идентификации акустических аномалий

А. О. Исхакова а, б, канд. техн. наук, старший научный сотрудник, orcid.org/0000-0001-8358-298X, iskhakova.ao@gmail.com

М. Д. Алёхинв , канд. техн. наук, начальник отдела, orcid.org/0000-0003-2091-2755

А. В. Богомолов ${ }^{\text {, }}$ доктор техн. наук, профессор, ведущий научный сотрудник, orcid.org/0000-0002-7582-1802

аИнститут проблем управления им. В. А. Трапезникова РАН, Профсоюзная ул., 65, Москва, 117997, РФ

бТомский государственный университет систем управления и радиоэлектроники, Ленина пр., 40, Томск, 634050, РФ

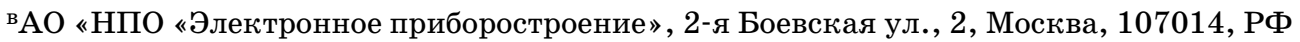

гФедеральный медицинский биофизический центр им. А. И. Бурназяна, Маршала Новикова ул., 23, Москва, 123098, РФ

Введение: создание новых подходов для решения прикладных задач эффективного сжатия аудиосигналов и их цифровой обработки является актуальной научной задачей, что подтверждается повышением интереса к новым методам распознавания паттернов для улучшения качества идентификации акустических аномалий. Цель: проведение сравнительного анализа времячастотных преобразований паттернов аудиосигналов, включая рассмотрение тестовой реализации нестационарного квазипериодического биомедицинского сигнала в задаче идентификации акустических аномалий. Результаты: проведен сравнительный анализ время-частотных преобразований (оконного Фурье; Габора; Вигнера; псевдо Вигнера; сглаженного псевдо Вигнера; Чои Вильямса; Бертрана; псевдо Бертрана; сглаженного псевдо Бертрана; вейвлет-преобразования) на основе систематизации их ведущих функциональных характеристик (существование базисных функций и их ограниченность; наличие нулевых моментов и биортогонального вида; возможность представления в двумерной форме и осуществления обратного преобразования; обработка в режиме реального времени; качество время-частотной локализации; управление время-частотным разрешением; подавление интерференции по времени и по частоте; относительная вычислительная сложность; реализация быстрого алгоритма вычислений) для задачи распознавания паттернов биомедицинских сигналов. Представлена сравнительная таблица оценок информативности рассмотренных время-частотных преобразований для анализа паттернов нестационарных квазипериодических биомедицинских сигналов. Практическая значимость: повышение эффективности интеллектуального анализа паттернов при разработке специальных алгоритмов цифровой обработки аудиосигналов для автоматизированной идентификации акустических аномалий, свойственных нестационарным квазипериодическим процессам при исследовании эффектов акустических воздействий на операторов эргатических систем, приводящих к изменению функциональных состояний. 
Ключевые слова - системный анализ, нестационарные квазипериодические процессы, распознавание образов, обработка биомедицинских сигналов, эргатические системы, функциональные состояния, эффекты воздействий, время-частотные преобразования, идентификация акустических аномалий, девиация частоты, шум.

Для цитирования: Iskhakova A. O., Alekhin M. D., Bogomolov A. V. Time-frequency transforms in analysis of non-stationary quasiperiodic biomedical signal patterns for acoustic anomaly detection. Инфорлационно-управляюшие систель, 2020 , № 1 , с. $15-23$. doi:10.31799/1684-8853-2020-1-15-23

For citation: Iskhakova A. O., Alekhin M. D., Bogomolov A. V. Time-frequency transforms in analysis of non-stationary quasiperiodic biomedical signal patterns for acoustic anomaly detection. Informatsionno-upravliaiushchie sistemy [Information and Control Systems], 2020, no. 1, pp. 15-23. doi:10.31799/1684-8853-2020-1-15-23

\section{УВАЖАЕМЫЕ АВТОРЫ!}

Научные базы данных, включая SCOPUS и Web of Science, обрабатывают данные автоматически. С одной стороны, это ускоряет процесс обработки данных, с другой - различия в транслитерации ФИО, неточные данные о месте работы, области научного знания и т. д. приводят к тому, что в базах оказывается несколько авторских страниц для одного и того же человека. В результате для всех по отдельности считаются индексы цитирования, снижая рейтинг ученого.

Для идентификации авторов в сетях Thomson Reuters проводит регистрацию с присвоением уникального индекса (ID) для каждого из авторов научных публикаций.

Процедура получения ID бесплатна и очень проста, есть возможность провести регистрацию на 12-ти языках, включая русский (чтобы выбрать язык, кликните на зеленое поле вверху справа на стартовой странице): https://orcid.org 